\title{
In Vitro Sustained Differentiation of Rat Colon Epithelial Stem Cells Marwa M Abu-Serie ${ }^{1 *}$, Maha A El Demellawy1, Mohamed El-Sayed² and Fatma El-Rashidy ${ }^{2}$
}

${ }^{1}$ Medical Biotechnology Department, Genetic Engineering and Biotechnology Research Institute, City for Scientific Research and Technology Applications (SRTA-City), New Borg El Arab, Alexandria, Egypt

${ }^{2}$ Biochemistry Department, Faculty of Science, Alexandria University, Egypt

\begin{abstract}
Colonic epithelium composes of various cell types including alkaline phosphate-expressing absorptive, mucussecreting goblet and neuroendocrine cells that are derived from stem cells through asymmetric division. The continuous renewal of stem cells occurs under the highly coordinated cellular redox state. In the current study, based on a comparison with other culture media, colon epithelial cells were able to be sustained in vitro with normal status for more than two months under the chosen culture condition; a-MEM medium containing $20 \%$ fetal bovine serum. The cultured epithelial cells had normal doubling time and normal morphological characteristics as examined by transmission electron microscope. Also, these cultured cells contained functional stem cells and maintained their differentiation potency of colon stem cells, compared with freshly isolated mucosal epithelial cells, as indicated by the maintaining of aldehyde dehydrogenase $1 \mathrm{~B} 1$ expression ( $11.31 \pm 0.45$ to $11.15 \pm 0.48)$, ability to reduce silver nitrate, alkaline phosphate activity $(0.513 \pm 0.007 \mathrm{mU} / \mu \mathrm{g}$ to $0.438 \pm 0.005 \mathrm{mU} / \mu \mathrm{g})$, mucin secretion $(34.71 \pm 0.714 \mu \mathrm{g} / \mathrm{ml}$ to $32.93 \pm 0.357 \mu \mathrm{g} / \mathrm{ml})$ in appropriate cellular redox state level $(-258.4 \pm 1.3 \mathrm{mV}$ to $-237.4 \pm 3.7 \mathrm{mV})$. The present study showed sustaining replication potential and functional differentiation of colonic epithelial stem cell population in this culture. The above culture system may be useful as an in vitro model for stemness, toxicological, and carcinogenesis studies.
\end{abstract}

Keywords: Colon epithelial cells; Stem cells; Differentiated epithelial stem cells; Morphological and functional characteristics; $a$-MEM medium

\section{Introduction}

The glandular colonic epithelium composes of various cell types including absorptive (enterocytes), mucus-secreting goblet, and enteroendocrine or neuroendocrine cells. All these colonic epithelial cells derived from the stem cells [1]. Such stem cells can be defined by aldehyde dehydrogenase (ALDH) 1 that has been considered as a marker for normal human colonic stem cells. The detoxification capacity of ALDH1B1, by protecting stem cells against oxidative insult, might underlie the well-recognized longevity of stem cells $[2,3]$. The continuous renewal of colonic stem cells is necessary for the maintenance of normal gut structure and function and it occurs through the highly coordinated and tightly regulated cellular redox state $\left(E_{h}\right)$ that has been implicated in cell cycle responses such as proliferation, differentiation, and apoptosis. The dynamics of cellular redox balance are achieved by maintenance of the thiol (GSH)-todisulfide (GSSG) status [4].

These differentiated colon epithelial cells are arranged in closely packed straight tubular glands or crypts [1]. Alkaline phosphatase (ALP) is a marker enzyme for brush borders and is expressed only by the differentiated enterocytes. Thus ALP is a useful tool for the identification of factors that govern the overall enterocyte differentiation program [5]. Enterocytes are responsible for the recovery of water and electrolytes from feces [1]. As feces pass along the large intestine and become progressively dehydrated, the mucus becomes increasingly important for protecting the mucosa from trauma. Mucus forms a gel that adheres to the epithelium, preventing invasion by colonic bacteria and protecting against damage by bacterial toxins and enzymes. Most of the protective effect of mucus is thought to relate to the presence of the predominant glycoprotein, mucin [6]. The neuroendocrine cells are the storage sites of the secretory products that are fundamental for the absorption, secretory and motile activities of the gut. Argentaffin or enterochromaffin cells which constitute the larger endocrine cell population contain granules able to reduce silver nitrate in the absence of a chemical reducer $[7,8]$.
Despite years of effort in many laboratories, it has proved to be impossible to establish epithelial cell lines from the normal adult colonic epithelium of rodents. The alternative approach taken by many researchers has been to use colon carcinoma cell lines such as HT-29, Caco-2, T84 and LoVo, etc [9]. In many respects, Caco-2 cell monolayer mimics the human intestinal epithelium and it is used as model transcellular pathways and metabolic transformation of test substances. One of the functional differences between normal cells and Caco- 2 cells is the lack of expression of the cytochrome P450 isozymes and in particular, CYP3A4, which is normally expressed at high levels in the intestine [10]. Another drawback of cell lines is the loss of tissue characteristics with passaging. Applicability for human pathogenesis will therefore have to be ascertained for any results that could obtain with colon cancer cell lines $[11,12]$.

As a result of advances in identification and culture of putative stem cells, interest in in vitro models of colonic epithelial cells has been rejuvenated. In particular, there is considerable interest in the regenerative potential of colonic stem/progenitor cells that populate epithelial cells $[13,14]$. The difficulty in producing stable cell lines likely relates to imperfect knowledge of tissue dissociation methods using mechanical disruption, chelating agents and proteolytic enzymes and culture conditions that are required to maintain cell proliferation and differentiation of epithelial stem cells [13]. The most widely

${ }^{*}$ Corresponding author: Marwa Muhammad Abu-Serie, Medical Biotechnology Department, Genetic Engineering and Biotechnology Research Institute, City for Scientific Research and Technology Applications (SRTA-City), New Borg El Arab, Alexandria, Egypt, Tel: +2034593422; Fax: +2034593407; E-mail: marwaelhedaia@gmail.com

Received: November 30, 2015; Accepted: January 09, 2016; Published January 13, 2016

Citation: Abu-Serie MM, El Demellawy MA, El-Sayed M, El-Rashidy F (2016) In Vitro Sustained Differentiation of Rat Colon Epithelial Stem Cells. Biochem Anal Biochem 5: 239. doi:10.4172/2161-1009.1000239

Copyright: ( 2016 Abu-Serie MM, et al. This is an open-access article distributed under the terms of the Creative Commons Attribution License, which permits unrestricted use, distribution, and reproduction in any medium, provided the original author and source are credited. 
used basal media for intestinal epithelium include alpha minimum essential medium ( $\alpha$-MEM) [15], high-glucose formulation Dulbecco's modified eagle's medium (DMEM) [16], Roswell Park Memorial Institute (RPMI) 1640 [9] and Ham's F-12 [17]. An issue that is acute to intestinal cell culture, particularly colon cells, is the avoidance of resident microbial contamination by adding penicillin $(100 \mathrm{IU} / \mathrm{ml})$ and streptomycin [18]. Another issue is that controversy about certain concentration of fetal bovine serum (FBS) must be supplemented basal medium to promote cell replication. Inclusion of FBS is believed to protect primary cells from osmotic shock, stabilize $\mathrm{pH}$, and provide several binding proteins like albumin and transferrin as well as certain growth factors, for example, epidermal growth factor (EGF), insulinlike growth factor, and transforming growth factor $[13,19,20]$. Thus, additional growth factors and the supplements include transferrin, sodium selenite and EGF, insulin and/or hydrocortizone have no effects in some previous studies [21,22].

Epithelia have been a focus of interest in the development of in vitro models for many years. Because most epithelia are renewable, they considered attractive models for studying the regulation of stem cell proliferation and differentiation. Beside this, many epithelia are originator sites for malignant transformation of the most common solid tumors therefore such cells could be adopted as appropriate models for studies of carcinogenesis [23]. Further, epithelial cells could be used as a model of intestinal absorption of drugs and other compounds [10].

\section{Materials and Methods \\ Colon epithelial cell culture}

Eight male Sprague-Dawely rats weighing from 85-95 g were maintained in accordance with the guidelines of the NIH and obtained from MISR University for Science and Technology (animal welfare assurance no. A5865-01). The animals were starved before cell isolation. Colon epithelial cells were isolated according to the method was described by Follmann et al. [24] with our modifications (patent code 1159/2014). Briefly, a modified method for colon mucosal crypt isolation was developed in this study based on single step of enzymatic digestion accompanied by mechanical disruption technique. The colon was incubated with $400 \mathrm{U}$ of type I collagenase (Sigma, USA) in $5 \%$ incubator at $37^{\circ} \mathrm{C}$ and then crypts were collected by centrifugation at $500 \mathrm{x} \mathrm{g}$ at RT for $5 \mathrm{~min}$. The pellets were washed twice with DMEM containing 10\% FBS (Lonza, USA).

The freshly prepared crypt pellets obtained from rat colons were resuspended in different growth media including a-MEM, highglucose formulation-DMEM, RPMI 1640 or Ham's F-12/ DMEM (1:1). Each of the above basal media was mixed with $2.5,5,10,15$ and $20 \%$ FBS. Cells in different culture media were plated at about 200 crypts per well into 12 -well culture plates and incubated at $37^{\circ} \mathrm{C}$ in a humidified atmosphere of $5 \% \mathrm{CO}_{2}$ (New Brunswick Scientific, Netherlands). After $24 \mathrm{~h}$, media were aspirated gently and fresh media were added to every well. Within 24-48 h, some crypts attached to the bottom of the wells and small cell patches began to form and start to expand.

\section{Estimation of cell doubling time in different culture conditions}

When cells reached $90 \%$ confluent (10 to 20 days), this cell patches were trypsinized then seeded in 96-well plates for estimation of cell doubling time under the different culture conditions by methylthiazolyl diphenyl-tetrazolium bromide (MTT) assay according to Mosmann [25] and morphologic changes were determined by phase-contrast inverted microscope (Olympus, Japan).
Five thousand colon epithelial cells were seeded per well in seven 96-well culture plates and allowed to adhere for $24 \mathrm{~h}$. Daily, over a period of seven days, media were removed and cells were incubated with $20 \mu \mathrm{l}$ of MTT solution ( $5 \mathrm{mg} / \mathrm{ml}$ in PBS, $\mathrm{pH} \mathrm{7}$ ) at $37^{\circ} \mathrm{C}$ for $4 \mathrm{~h}$. MTT solution (Sigma-Aldrich, USA) was removed and the insoluble blue formazan crystals that trapped in cells were solubilized with $150 \mu \mathrm{l}$ of $100 \%$ DMSO. The absorbance of each well was measured at $630 \mathrm{~nm}$ using a microplate reader. The viable cell number is proportional to the absorbance using the standard curve that was generated by seeding a serial dilution of cells at $5 \times 10^{3}-4 \times 10^{4}$ cells/well in 96-well culture plate and assayed as mentioned above. The cell doubling time was estimated according to the following equation: The incubation time $x \ln 2 / \ln$ (The cell number at the end of the incubation time / the cell number at the beginning of the incubation time). Where, the cell number was calculated using the standard curve that was generated by seeding a serial dilution of cells at $5 \times 10^{3}-4 \times 10^{4}$ cells/well in 96-well culture plate

\section{Morphological examination of cultured colon epithelial cells}

The epithelial cells in the most optimum media were subcultivated after detachment with trypsin/EDTA solution (Lonza, USA) and could be cultured for several weeks. The morphological examination of cultivated colon epithelial cells was performed using transmission electron microscope (TEM) as described by Ichinose et al. [26] and Tolivia et al. [27].

About $3 \times 10^{6}$ cells in the most optimum media were collected and fixed in 3\% glutaraldehyde: formaldehyde (4:1) in phosphate buffer saline for at least $1 \mathrm{~h}$, recentrifuged for $5 \mathrm{~min}$ at $4^{\circ} \mathrm{C}$ three times with $0.1 \mathrm{M}$ phosphate buffer saline at $1000 \mathrm{rpm}$. The pellet was fixed in $1 \%$ osmium tetroxide at $4^{\circ} \mathrm{C}$ for $1 \mathrm{~h}$, washed three times in phosphate buffer saline, dehydrated in ascending grades of alcohols and changed three times in epoxy resin. Epoxy resin (epon) was polymerized at $37^{\circ} \mathrm{C}$ overnight and at $60^{\circ} \mathrm{C}$ for another $48 \mathrm{~h}$. Further processing for the above epon capsules was done in which ultrathin sections of $0.5-1 \mu \mathrm{m}$ thickness were obtained and stained with uranyl acetate followed by lead citrate for examination by TEM (Jeol, Japan).

\section{Molecular and biochemical characterization of the cultivated colon epithelial cells}

The molecular and biochemical assays were performed in order to ensure that all types of colon epithelial cells maintained their normal cell characteristics of the tissue of origin during subculturing for more than 2 months. Accordingly, each subculture (P; passage) was compared with control of freshly isolated colon mucosal crypt cells.

\section{Determination of ALDH1B1 expression level of colon epithelial stem cells}

RNA was extracted from cells using RNA purification Kit, reversetranscribed into cDNA and subjected to real-time PCR according to according to the manufacturer's Quantitative real-time-PCR kit (Thermo Scientific, USA). Primer sequences of ALDH1B1 were forward, 5'-GACCGGAGAACG CTGATACTAGA-3' and reverse, 5'-GGGATTGGGTTCGGGAGA-3' and 18S rRNA as housekeeping gene were forward, 5'-CGGCTACCACATCCAAGGAA- $3^{\prime}$ and reverse, 5'-GCTGGAATTACCGCGGCT-3' (Bio-Basic INC, Canada). Samples were placed in the cycler (Qiagen, Germany) and cycling conditions were $50^{\circ} \mathrm{C}$ for $2 \mathrm{~min}, 95^{\circ} \mathrm{C}$ for $10 \mathrm{~min}$, followed by 40 cycle of $95^{\circ} \mathrm{C}$ for $15 \mathrm{sec}, 56^{\circ} \mathrm{C}$ for $30 \mathrm{sec}$ and $72^{\circ} \mathrm{C}$ for $30 \mathrm{sec}$. The relative quantification of $\mathrm{ALDH} 1 \mathrm{~B} 1(\Delta \mathrm{Ct})$ was calculated using the following equation: cycle threshold $(\mathrm{Ct})$ of ALDH1B1- Ct of $18 \mathrm{~S}$ rRNA. 


\section{Determination of ALP activity of colon epithelial enterocyte cells}

It was performed according to the manufacturer's Spectrum kit (Egypt).

\section{Determination of mucin level of colon epithelial goblet cells}

A sensitive colorimetric assay for detecting mucin was described by Bhavanandan et al. [28]. Ten microliters of $0.13 \mathrm{M}$ sodium borate buffer, $\mathrm{pH} 10$ was added to $30 \mu \mathrm{l}$ of cell lysates or mucin standard in 96-well plate and mixed by shaking the plate for $5 \mathrm{~min}$. The plate was heated in an oven at $80^{\circ} \mathrm{C}$ for $2 \mathrm{~h}$. The plate was cooled to RT and centrifuged at $2000 \mathrm{rpm}$ for $5 \mathrm{~min}$. Two hundred microliters of $10 \%$ Ehrlich's reagent (Sigma-Aldrich, USA) were added and the plate was incubated at $37^{\circ} \mathrm{C}$ for $20 \mathrm{~min}$ then the absorbances were measured at $450 \mathrm{~nm}$ using a plate reader. The sample mucin concentration was calculated using the standard curve.

\section{Fontana-Masson silver stain for detection of colon epithelial enteroendocrine cells}

The maintenance of enteroendocrine epithelial cells was assessed by silver staining to their granules as described by Bancroft and Gamble [29]. Cells were washed with PBS buffer by centrifugation (Hettich, Germany) at $600 \mathrm{xg}$ for $5 \mathrm{~min}$ at RT and $10 \%$ formalin in PBS was added to cell pellets. The fixed cell specimens were dehydrated in ascending grades of alcohol then cleaned by immersion in xylene for one hour (three times) followed by impregnation in melted paraffin and embedding to form solid paraffin blocks. Then a rotator microtome was used to cut block into $5 \mu \mathrm{m}$ thick sections that were transferred into clean glass slides. The sections were immersed in ammoniacal silver working solution and incubated in a microwave for 3 cycles of 50 sec then followed by three washes in distilled water. The sections were differentiated in $2 \%$ gold chloride (Sigma-Aldrich, USA) for $5 \mathrm{~min}$ then fixed with $2 \%$ sodium thiosulfate for $1 \mathrm{~min}$. The images of fixed cells were captured using phase contrast microscope with digital camera (Olympus, Japan).

\section{Determination of cellular redox potential $\left(\mathrm{E}_{\mathrm{h}}\right)$ level}

Cellular levels of GSH and GSSG are useful as an index of cell development stages [30] and oxidative stress [31]. Glutathione (SigmaAldrich, USA) was determined by a slight variation of Griffith's [32] modification of Tietze's [33] assay. The cellular $\mathrm{E}_{\mathrm{h}}$ values were calculated using the Nernst equation (in $\mathrm{mV}$ ) for the respective GSH/GSSGpools: $-264+30 \log \left([\mathrm{GSSG}] /[\mathrm{GSH}]^{2}\right)[34]$

\section{Statistical Analysis}

Data were expressed as mean \pm standard error of the mean (SEM) by the multiple comparisons one-way analysis of variance (ANOVA) using SPSS16 software program at probability (p)- values $<0.05$ were considered statistically significant.

\section{Results}

The effect of different types of media and different concentrations of FBS on the proliferation of the isolated and cultivated epithelial cells was illustrated by doubling time (Figure 1A). These data showed that cell doubling time decreased significantly with the increase in the concentration of FBS in the different media, where, the shortest doubling time of epithelial cells was at $20 \%$ FBS contained culture media. As presented in Figure $1 \mathrm{~B}$ that the isolated epithelial cells proliferated exponentially, in both $\alpha$-MEM and DMEM culture media, but the cell growth took less time in a-MEM than in DMEM culture medium. Doubling time of cells cultivated in a-MEM $(3.14 \pm 0.03)$ and DMEM $(5.23 \pm 0.18)$ culture media showed a significant decrease compared to that of cells cultivated in RPMI $1640(8.47 \pm 0.23)$ and Ham's F-12/ DMEM (10.45 \pm 0.27$)$ culture media. These data were supported by healthy and ideal morphology of confluent epithelial cells cultivated in $\alpha$-MEM and DMEM culture media as compared to that cultivated in RPMI and Ham's F-12/ DMEM (1:1) culture media (Figure 2).

The phase contrast examination of cultured colon epithelial cells (at the last passage) confirmed that cells cultured in 20\% FBS a-MEM maintained their normal spindle shape, while that cultured in 20\% FBS DMEM lose their normal shape as illustrated in Figure 3. Moreover, morphological characteristics of the isolated and cultured rat colon epithelial cells (P 3) were examined by TEM (Figure 4) showed microvilli on the cell membrane, tight junctions and desmosomes between neighbouring cells. These morphological ultrastructures also demonstrated the high differentiation status of the cultured epithelial stem cells that their cytoplasm contained mucinogen granules of goblet cells, absorptive vacuoles of enterocytes and myelin filaments of neuroendocrine cells (Figure 4A-C). In addition, Figure 4A and 4B showed normal shape of nuclei of epithelial cells that cultured in $\alpha$-MEM from P 3 and until the last P 17 in comparison with irregular nuclear shape of cells cultured in DMEM at P 3 (Figure 4C) and apoptotic cells cultured in DMEM at P 8 (Figure 4D). Apoptotic cells were identified by apoptotic bodies in their cytoplasm, nuclear shrinkage and DNA fragmentation paralleled with chromatin condensation [35,36] as shown in Figure 4D.

$\mathbf{A}$
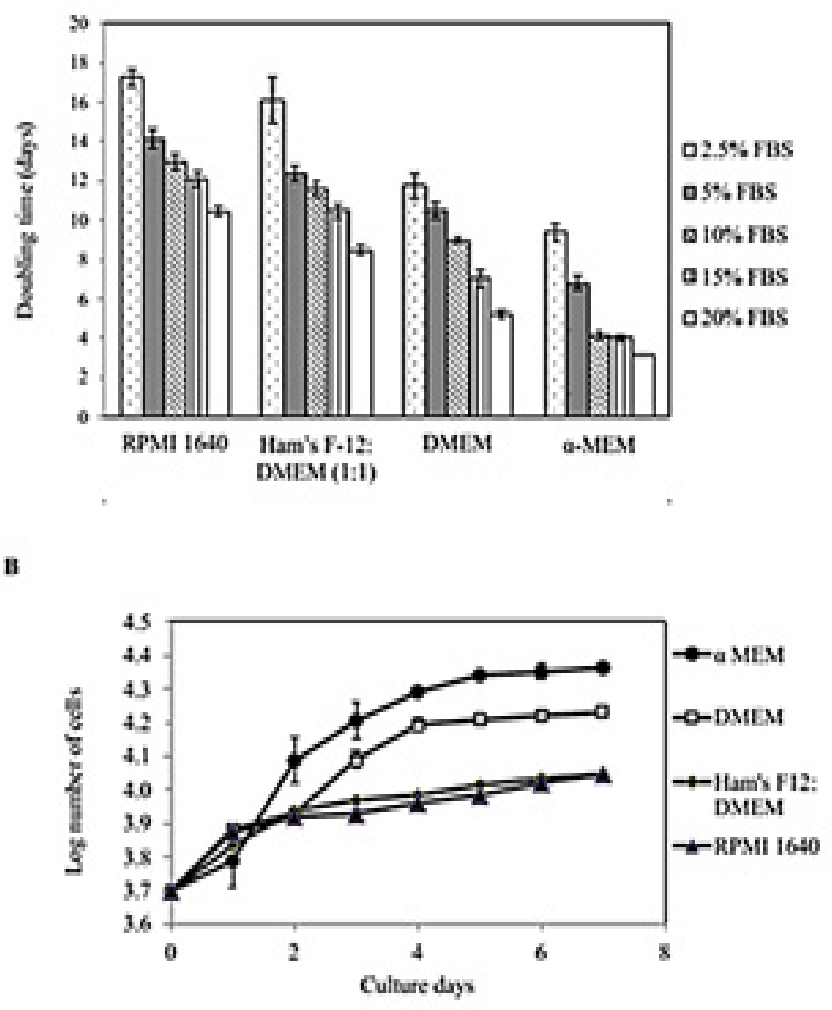

Figure 1: (A) The doubling time of colon epithelial cells cultured in differen culture media. (B) Growth curve of colon epithelial cells cultured in different culture media supplemented with $20 \%$ FBS. 
Citation: Abu-Serie MM, El Demellawy MA, El-Sayed M, El-Rashidy F (2016) In Vitro Sustained Differentiation of Rat Colon Epithelial Stem Cells. Biochem Anal Biochem 5: 239. doi:10.4172/2161-1009.1000239

Page 4 of 8

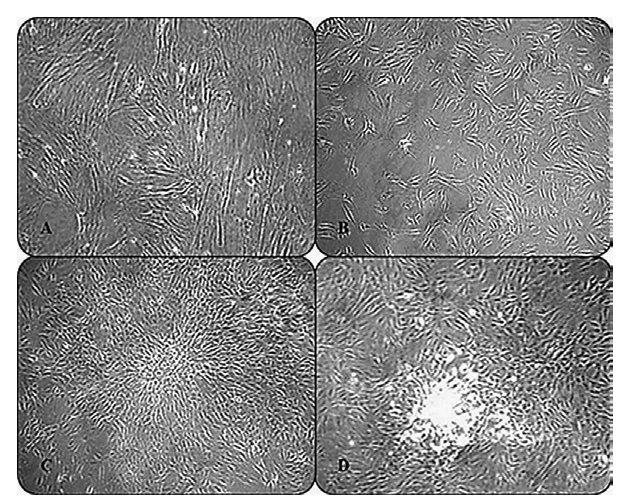

Figure 2: The confluent colon epithelial cells cultured in different media containing 20\% FBS. (A) RPMI 1640, (B) Ham's F-12: DMEM (1:1), (C) DMEM, and (D) a-MEM (Magnification $\times 200$ ).

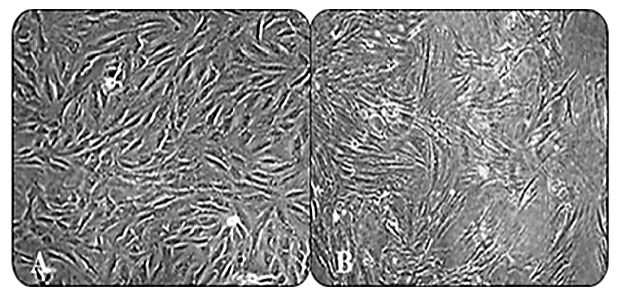

Figure 3: Colon epithelial cells (at the late passage) cultured in (A) a-MEM containing $20 \%$ FBS at P 17 and (B) DMEM containing $20 \%$ FBS at P 8 (Magnification $\times 400$ ).
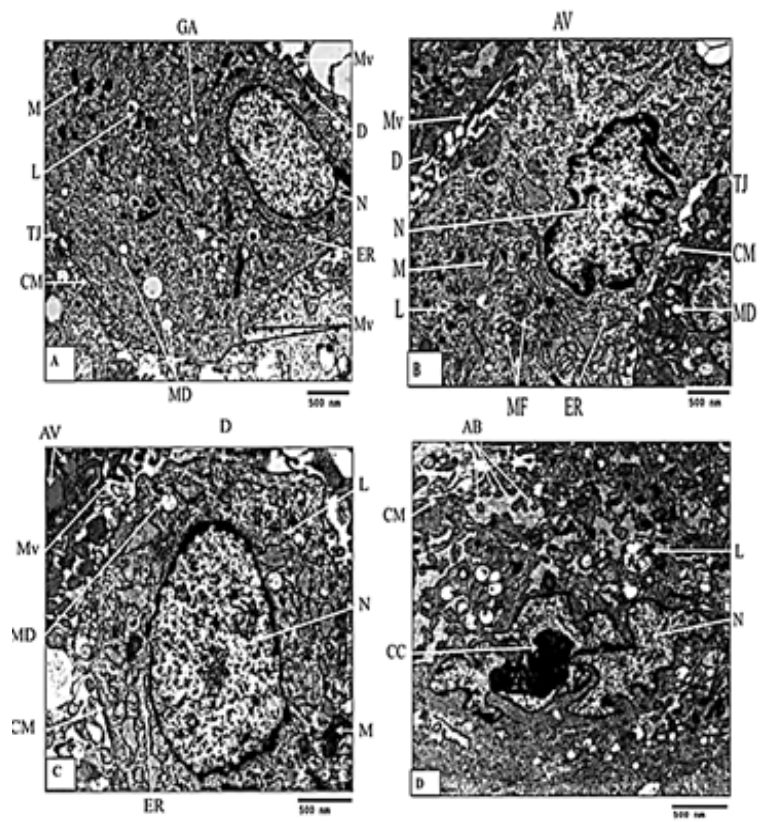

Figure 4: Transmission electron micrographs of rat colon differentiated epithelial cells (P3) cultured in (A) a-MEM containing 20\% FBS (P3) and (B) DMEM containing 20\% FBS (P3) (Bar $500 \mathrm{~nm}, 3000 \mathrm{x}$ ). Rat colon epithelia cells (late passage) cultured in (C) a-MEM containing $20 \%$ FBS and (D) DMEM containing 20\% FBS (Bar $0.5 \mathrm{~mm}, 4000 \mathrm{x}$ ). AB: Apoptotic Bodies; AV: Absorptive Vacuoles; CC: Condensed Chromatin; CM: Cell Membrane; D: Desmosome; ER: Endoplasmic Reticulum; GA: Golgi Apparatus; L: Lysosome; M: Mitochondria; MD: Mucous Droplets; MF: Myelin Filaments; Mv: Microvilli; N: Nucleus; TJ: Tight Junction
Hence, the morphological examinations using light and electron microscopy were supported with molecular and biochemical characterization of the cultivated colon epithelial cells. Maintenance of epithelial stem cells was identified by their expression level of cytosolic enzyme ALDH1B1 during cell passaging compared with freshly isolated epithelial cells. Figure 5 illustrates that no significant change in relative expression of ALDH1B1 (11.31 \pm 0.45 to $11.15 \pm 0.48)$ during passaging of epithelial stem cells cultured in $\alpha$-MEM while epithelial stem cells cultured in DMEM was associated with a significant reduction in the expression level of ALDH1B1 (11.14 \pm 0.47 to $0 \pm 0$ ) after P 4 (23 days).

Furthermore, Figures 6 and 7 show that colon epithelial cells (enterocyte and goblet cells) cultured in a-MEM culture medium were function normally over 17 passages $(0.513 \pm 0.007 \mathrm{mU} / \mu \mathrm{g}$ to $0.438 \pm 0.005 \mathrm{mU} / \mu \mathrm{g}$ and $34.71 \pm 0.714 \mu \mathrm{g} / \mathrm{mL}$ to $32.93 \pm 0.357 \mu \mathrm{g} /$ $\mathrm{mL}$, respectively) as compared to basal activity of freshly isolated colon epithelial cells $(0.424 \pm 0.013 \mathrm{mU} / \mu \mathrm{g}$ and $29.7 \pm 1.43 \mu \mathrm{g} / \mathrm{mL}$, respectively). In addition to the black deposits appears in differentiated neuroendocrine cells of epithelial cells cultured in a-MEM without change during passaging as shown in Figure 8B and 8D. In contrast, a significant decrease in ALP activity $(0.519 \pm 0.003 \mathrm{mU} / \mu \mathrm{g}$ to $0.132 \pm 0.03 \mathrm{mU} / \mu \mathrm{g})$ and mucin level $(38.29 \pm 1.43 \mu \mathrm{g} / \mathrm{mL}$ to $5.43 \pm 1.43$ $\mu \mathrm{g} / \mathrm{mL}$ ) of epithelial cells cultured in DMEM culture medium after P4 (Figures 6 and 7). Moreover, neuroendocrine cells cultured in DMEM disappeared gradually with time as shown in Figure 8C until disappear completely in Figure 8E at P8 compared with scattered neuroendocrine cells in the freshly isolated crypt cells (Figure 8A).

During cell passaging in a-MEM culture medium, GSH/GSSG level (4.94 \pm 0.504 to $2.94 \pm 0.48)$ remained high with no significant change at $\mathrm{P} 3,6,9$ and 17 that is coupled with cell proliferation which have $\mathrm{E}_{\mathrm{b}}$ values ranging from $-260.4 \pm 1.5 \mathrm{mV}$ to $-237.4 \pm 3.7 \mathrm{mV}$. While GSH/ GSSG level (5.72 \pm 0.26 to $1.49 \pm 0.0)$ of cells subcultured in DMEM culture medium is elevated transiently until P 2 with no significant change at $\mathrm{P} 3,4$ and 5 coupled with proliferation $\left(\mathrm{E}_{\mathrm{h}}=-257.7 \pm 1.2 \mathrm{mV}\right.$ to $-230.9 \pm 0 \mathrm{mV})$. Then GSH/GSSG level $(0.297 \pm 0.02$ to $0.102 \pm 0)$ depleted significantly at $\mathrm{P} 7$ and 8 where cells transited to differentiation state at $\mathrm{P} 7\left(\mathrm{E}_{\mathrm{h}}=-191.6 \pm 0.8 \mathrm{mV}\right)$ and finally to apoptosis with $\mathrm{E}_{\mathrm{h}}$ equals to $-151.1 \pm 0 \mathrm{mV}$ at $\mathrm{P} 8$ as shown in Table 1 .

\section{Discussion}

Culture medium is the most important and complex factor that control optimum cell growth. Cell culture media generally provide appropriate source of energy and cell cycle regulator. A typical culture medium is composed of a complement of amino acids, vitamins, inorganic salts, glucose, and serum [37]. The major functions of FBS in culture media are to provide hormones and growth factors stimulating cell proliferation. Also FBS promotes differentiated functions via a specific transcriptional activation program, such as MAPK/ extracellular signal-regulated kinase (ERK) cascade, that is needed to initiate cell growth in vitro [38] by EGF [39] or platelet derived growth factor (PDGF) [40]. The crypt cells are mainly differentiated cells without a dividing potential and stem cells may account for $<5 \%$, which explain the weaker effect of growth factors exogenously added to the culture medium [22].

In vitro cultivation of isolated colon epithelial cells depends mainly on the quality of the basal culture medium and its constituents, especially the concentration of FBS [41]. This current study demonstrated that the most appropriate culture media are $\alpha$-MEM and DMEM supplemented with $20 \%$ FBS based on in vivo doubling time of epithelial cells within 5 days [30]. This result disagrees with the results reported by Whitehead 


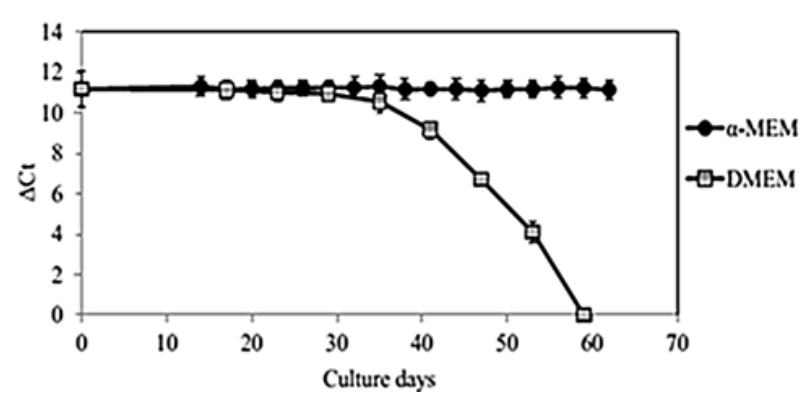

Figure 5: ALDH1B1 expression levels during colon epithelial cells subculturing in $\alpha-M E M$ and DMEM culture media

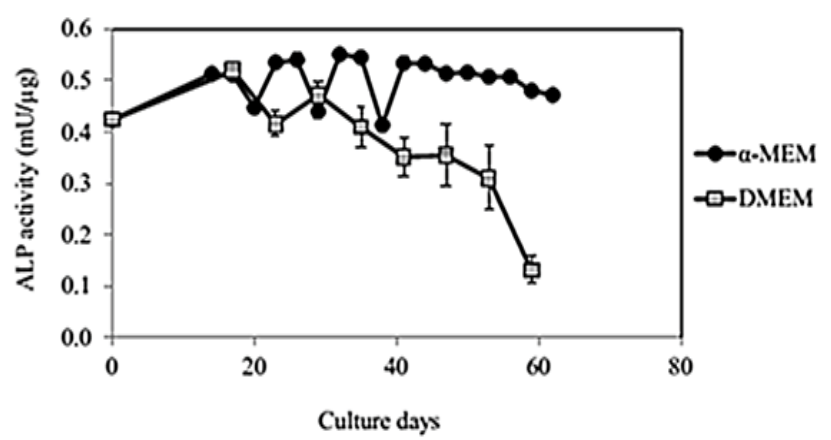

Figure 6: ALP activity during colon epithelial cells subculturing in $\alpha-M E M$ and DMEM culture media.

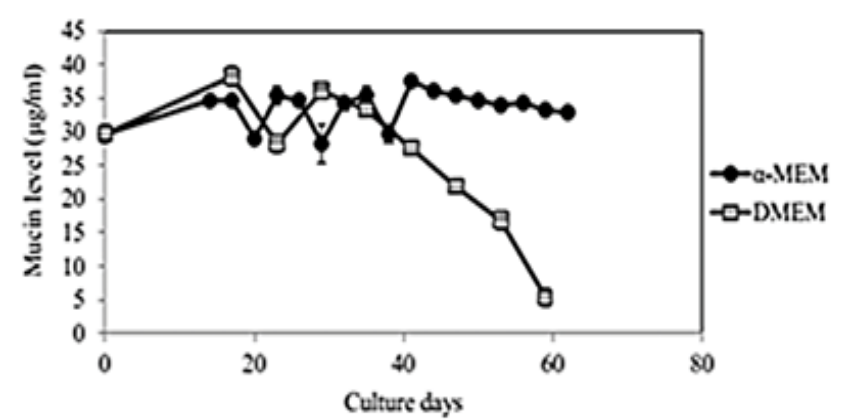

Figure 7: Mucin levels of colon epithelial cells during subculturing in a-MEM and DMEM culture media.

and Robinson who cultured crypts liberated from adult mouse colon in RPMI 1640 containing 5\% FBS. Also is disagreed with results elaborated by Nikoulina et al. [17] who developed a primary mouse colonic crypt model enriched for enteroendocrine cells by culturing crypts in Ham's F-12/ DMEM containing 10\% FBS.

Calcium is one of inorganic salts in basal media and its concentration may be affected the growth and differentiation properties of normal epithelial cells via $\mathrm{Ca}^{2+}$-sensing receptor (CaSR) [42]. Activation of this receptor by extracellular $\mathrm{Ca}^{2+}$ modulates the activities of MAPK and tyrosine kinases associated with cell proliferation $[43,44]$. However, Youshimura et al. [45] demonstrated that lower calcium concentration did not affect proliferation. Calcium concentration in RPMI 1640 was $0.42 \mathrm{mM}$ and $0.3 \mathrm{mM}$ in Ham's F-12 whereas DMEM and $\alpha$-MEM contain $1.8 \mathrm{mM}$ calcium. This variation in calcium concentration may have played an important role in the increment in doubling time of colon epithelial cells cultivated in RPMI 1640 and Ham's F-12/ DMEM
(1:1) culture media compared with colon epithelial cells cultivated in a-MEM and DMEM culture media [46].

The phase contrast and TEM examinations ascertained that cells cultured in 20\% FBS a-MEM maintained their normal spindle shape, nuclear shape and differentiation status, while that cultured in $20 \%$ FBS DMEM lose their normal shape with irregular nuclear shape of apoptotic cells. Irregular shape of nucleus is a sign of onset of premature aging. Replicative senescence can result from inadequate culturing conditions. When cells are explanted from an organism and placed in culture, they have to adapt to an artificial environment, characterized by abnormal concentrations of nutrients that may induce a culture shock, resulting in stress-induced senescence after a number of passages in culture. Consistent with this, epithelial stem cells depend largely on the composition of the culture medium used. Thus, the immortalization of mammalian cells requires specific culture conditions [47].

The normal morphological characterizations of the cultivated colon epithelial cells in $20 \%$ FBS a-MEM corroborated the maintenance of epithelial stem cells that were identified by ALDH1B1. ALDH1B1 acts as a protector of stem cell against oxidative stress insult via catalytically oxidize aldehydes [3]. The toxicity of aldehydes is caused by it covalently binding biological macromolecules, such as proteins, lipid and nucleic acids and forming adducts that impair their functions [48]. A fast aldehyde detoxification mechanism is essential for maintaining high asymmetrical dividing potential of stem cells [49] that was preserved in $\alpha$-MEM and lost in DMEM after P 4 (23 days). Sustainability of differentiation potential of colon stem cells was observed by their cellular ALP activity and mucin level, so stem cells undergone normal proliferation and differentiation pattern. Follmann et al. [24] reported that ALP activity of bovine colon epithelial cells, cultured for 6 days in DMEM medium containing $10 \%$ FBS, decreased to about $50 \%$ of the basal activity found in freshly isolated cells.

Expression of a particular cell phenotype in culture depends on culture medium and culture time [50]. These media have different characteristics, DMEM is a less nutrient-rich medium with respect to amino acids and vitamins, although, nutrient concentrations are higher than those found in $\alpha-M E M$ and contains four times the concentration of glucose (about $4.5 \mathrm{~g} / \mathrm{l}$ ) than a-MEM [51]. It may be concluded that variation between the components of each applied medium can differentially influence cell proliferation and differentiation. Indeed, glucose may also affect proliferation and differentiation potential of stem cells [52]. Studies by Larsen et al. [53], Li et al. [54] and Kim et al. [55] have demonstrated that high glucose induced cellular senescence, while reduction of glucose enhanced proliferation.

Mucosal cells proliferation, together with differentiation and apoptosis, are a continuous homeostatic process in the intestinal epithelium. The GSH/GSSG redox status plays a key role in epithelial stem growth control wherein a reduced redox potential maintains a proliferative state. An oxidative shift in this potential elicits growth arrest and cell transition to a differentiated or apoptotic phenotype [56]. Proliferating cells have $\mathrm{E}_{\mathrm{h}}$ values ranging from $-260 \mathrm{mV}$ to -230 $\mathrm{mV}$. This pool becomes oxidized ( $\mathrm{E}_{\mathrm{h}}$ range: $-220 \mathrm{mV}$ to $-190 \mathrm{mV}$ ) on growth arrest due to differentiation. Cells undergoing apoptosis are further oxidized and the $\mathrm{E}_{\mathrm{h}}$ rang become $-170 \mathrm{mV}$ to $-165 \mathrm{mV}$ [30].

Colon epithelial cells cultured in DMEM culture medium, showed slower doubling time elicited a decrease rather than an increase in cellular GSH to GSSG status that refer to replicative senescence of cells [57]. Then started to become oxidized in response to oxidative stress that leading to cell growth arrested due to GSH depletion associated 


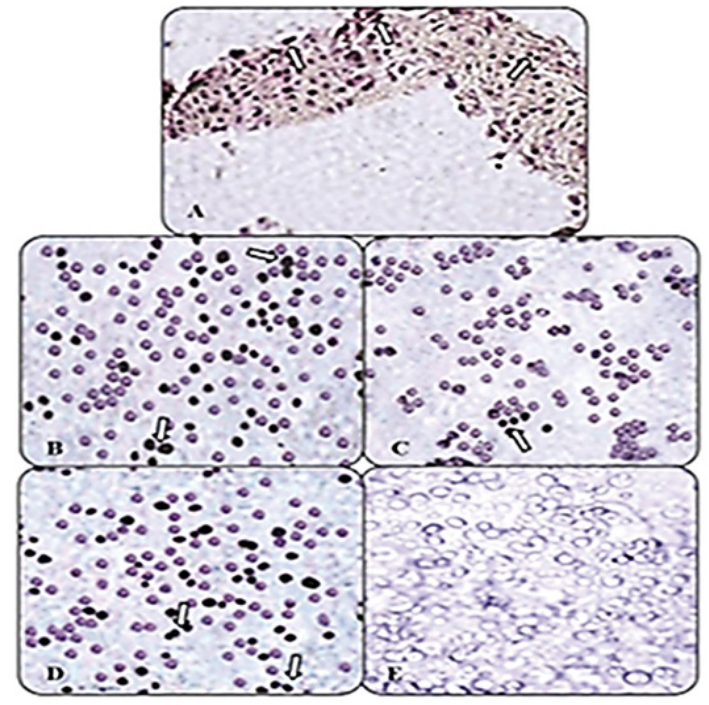

Figure 8: Colonic epithelial neuroendocrine cells (arrows) were detected by Fontana-Masson silver method. (A) Freshly isolated crypt cells, (B, D) cells cultured in a-MEM medium at $P 3$ and $P 17$, respectively, and (C,E) cells cultured in DMEM medium at $P 3$ and $P 8$, respectively (Magnification $\times 400$ ).

\begin{tabular}{|c|c|c|c|c|c|c|}
\hline \multirow{2}{*}{$\begin{array}{l}\text { Culture } \\
\text { days }\end{array}$} & \multicolumn{3}{|c|}{ a-MEM } & \multicolumn{3}{|c|}{ DMEM } \\
\hline & $(P)$ & $E_{h}(m V)$ & $\begin{array}{l}\text { Cell growth } \\
\text { state }\end{array}$ & (P) & $E_{h}(m V)$ & $\begin{array}{l}\text { Cell growth } \\
\text { state }\end{array}$ \\
\hline $\begin{array}{l}\text { Freshly } \\
\text { isolated } \\
\text { cells }\end{array}$ & $(0)$ & $-247.5 \pm 1.8$ & Proliferation & (0) & $-247.5 \pm 1.8$ & Proliferation \\
\hline 17 & $(2)$ & $-260.02 \pm 2^{a}$ & Proliferation & (1) & $-257.7 \pm 1.2^{\mathrm{a}}$ & Proliferation \\
\hline 23 & $(4)$ & $-258.7 \pm 0^{\mathrm{a}}$ & Proliferation & (2) & $-249.1 \pm 1.3$ & Proliferation \\
\hline 29 & $(6)$ & $-243.7 \pm 1.1$ & Proliferation & (3) & $-242 \pm 0.6^{a}$ & Proliferation \\
\hline 35 & $(8)$ & $-256.9 \pm 1.5^{a}$ & Proliferation & (4) & $-237.5 \pm 0.1^{a}$ & Proliferation \\
\hline 41 & (10) & $-259.7 \pm 1.3^{a}$ & Proliferation & (5) & $-230.9 \pm 0^{a}$ & Proliferation \\
\hline 44 & (11) & $-256.9 \pm 1.5^{\mathrm{a}}$ & Proliferation & & & \\
\hline 47 & (12) & $-250.6 \pm 3.1$ & Proliferation & (6) & $-225 \pm 1.4^{a}$ & $\begin{array}{l}\text { Growth arrest } \\
\text { and start } \\
\text { of terminal } \\
\text { differentiation }\end{array}$ \\
\hline 50 & (13) & $-251.9 \pm 1.1$ & Proliferation & & & \\
\hline 53 & (14) & $-249.4 \pm 1.3$ & Proliferation & (7) & $-191.6 \pm 0.8^{a}$ & $\begin{array}{c}\text { Terminal } \\
\text { differentiation }\end{array}$ \\
\hline 56 & (15) & $-250.7 \pm 0.5$ & Proliferation & & & \\
\hline 59 & (16) & $-245.9 \pm 4.8$ & Proliferation & (8) & $-164.7 \pm 0^{a}$ & Apoptosis \\
\hline 62 & (17) & $-237.4 \pm 3.7^{a}$ & Proliferation & & & \\
\hline
\end{tabular}

Data are expressed as mean \pm SEM and compared with afreshly isolated cells ( $P$ $0)$. Significance level is at $p<0.05$

Table 1: The cellular $E_{h}$ during colon epithelial cells subculturing in $\alpha-M E M$ and DMEM culture media.

with inhibition of telomerase activity [58,59]. Then cells entered terminal differentiation is usually coupled with permanent exit from the cell cycle. At the last passage, cells become more oxidized $\mathrm{E}_{\mathrm{h}}$ (too positive), resulting from severe oxidative stress, then death signals was activated and apoptosis was initiated [59] as shown in Figure 4F.

On the contrary, colon epithelial stem cells cultured in a-MEM culture medium were actively proliferating for more than two months that was consistent with maintenance of a reduced $\mathrm{E}_{\mathrm{h}}$. Reduced environment requires for DNA binding to more than 62 proteins, including transcription factors, an essential process for cell cycle progression [60]. Further, GSH stimulates growth factor via autophosphorylation of growth factor receptor that is correlated with enhanced DNA synthesis and cell entry into $S$ phase [61]. Proliferation of epithelial cells occurred via asymmetric division to stem cell (selfrenew) and differentiated cells "goblet, enterocyte and enteroendocrine cells" [62]. When GSH/GSSG became a slightly less reducing ( $E_{b}$ be a more positive), the differentiation switched can be turned on while proliferation decreased [4].

\section{Conclusions}

The key features of the normal intact rat colon mucosal epithelial cells maintained with active proliferation of stem cells in culture for 62 days when $a$-MEM medium containing $20 \%$ FBS was used without any additional growth factors. Where, these cultured epithelial cells had normal doubling time and normal morphological characteristics and contained different differentiated epithelial cell types (enterocyte, goblet, and enteroendocrine) in appropriate redox environment as confirmed by GSH/GSSG Eh level. In DMEM medium containing $20 \%$ FBS culture medium, epithelial cells loss of intestinal homeostasis with time and had apoptotic features, a significant down regulation of ALDH1B1 expression, a defect in activity of ALP and secretion of mucin as well as gradually disappearance of black deposit in neuroendocrine cells. This study showed replication potential and functional differentiation, ensuring that stem cell population sustained in this culture (a-MEM medium containing 20\% FBS) that may attribute to variation in ingredients and their concentrations between $\alpha$-MEM medium and DMEM medium.

\section{Acknowledgment}

We acknowledged all staff members of Electron Microscopy Unit, Faculty of Science, Alexandria University for their help in the identification of isolated colon epithelial cells.

\section{Compliance with Ethical Requirements and Conflict of Interest}

Marwa M Abu-Serie, Maha A El Demellawy, Mohamed El-Sayed and Fatma El-Rashidy state that they have complied with all ethical requirements during the preparation of this manuscript and declare that they have no conflict of interest and no financial interest. All applicable international, national, and/or institutional guidelines for the care and use of animals were followed.

\section{References}

1. Tanaka T (2009) Colorectal carcinogenesis: Review of human and experimental animal studies. J Carcinog 8: 5

2. Huang EH, Hynes MJ, Zhang T, Ginestier C, Dontu G, et al. (2009) Aldehyde dehydrogenase 1 is a marker for normal and malignant human colonic stem cells (SC) and tracks SC overpopulation during colon tumorigenesis. Cancer Res 69: 3382-3389.

3. Crabb DW, Matsumoto M, Chang D, You M (2004) Overview of the role of alcohol dehydrogenase and aldehyde dehydrogenase and their variants in the genesis of alcohol-related pathology. Proc Nutr Soc 63: 49-63.

4. Cereser C, Boget S, Parvaz P, Revol A (2001) Thiram-induced cytotoxicity is accompanied by a rapid and drastic oxidation of reduced glutathione with consecutive lipid peroxidation and cell death. Toxicology 163: 153-162.

5. Hinnebusch BF, Siddique A, Henderson JW, Malo MS, Zhang W, et al. (2004) Enterocyte differentiation marker intestinal alkaline phosphatase is a targe gene of the gut-enriched Kruppel-like factor. Am J Physiol Gastrointest Liver Physiol 286: 23-30

6. Finnie IA, Dwarakanath AD, Taylor BA, Rhodes JM (1995) Colonic mucin synthesis is increased by sodium butyrate. Gut 36: 93-99.

7. Christofi FL (2008) Purinergic receptors and gastrointestinal secretomotor function. Purinergic Signal 4: 213-236.

8. Heitz P, Polak JM, Timson DM, Pearse AG (1976) Enterochromaffin cells as the endocrine source of gastrointestinal substance $P$. Histochemistry 49: 343-347. 
9. Whitehead RH, Robinson PS (2009) Establishment of conditionally immortalized epithelial cell lines from the intestinal tissue of adult normal and transgenic mice. Am J Physiol Gastrointest Liver Physiol 296: 455-460.

10. van Breemen RB, Li Y (2005) Caco-2 cell permeability assays to measure drug absorption. Expert Opin Drug Metab Toxicol 1: 175-185.

11. Marian B (2004) Colorectal cancer: Modeling causes, prevention and therapy. Drug Discov Today: Dis Models 1: 1-7.

12. Friedman E, Urmacher C, Winawer S (1984) A model for human colon carcinoma evolution based on the differential response of cultured preneoplastic premalignant, and malignant cells to 12-O-tetradecanoylphorbol-13-acetate. Cancer Res 44: 1568-1578

13. Chopra DP, Dombkowski AA, Stemmer PM, Parker GC (2010) Intestinal epithelial cells in vitro. Stem Cells Dev 19: 131-142.

14. Dekaney CM, Rodriguez JM, Graul MC, Henning SJ (2005) Isolation and characterization of a putative intestinal stem cell fraction from mouse jejunum. Gastroenterology 129: 1567-1580.

15. Weng XH, Beyenbach KW, Quaroni A (2005) Cultured monolayers of the dog jejunum with the structural and functional properties resembling the normal epithelium. Am J Physiol Gastrointest Liver Physiol 288: 705-717.

16. Bartsch I, Zschaler I, Haseloff M, Steinberg P (2004) Establishment of a longterm culture system for rat colon epithelial cells. In Vitro Cell Dev Biol Anim 40: 278-284.

17. Nikoulina SE, Andon NL, McCowen KM, Hendricks MD, Lowe C, et al. (2010) A primary colonic crypt model enriched in enteroendocrine cells facilitates a peptidomic survey of regulated hormone secretion. Mol Cell Proteomics 9: 728-741.

18. Yeh KY, Chopra DP (1980) Epithelial cell cultures from the colon of the suckling rat. In Vitro 16: 976-986.

19. Masui T, Wakefield LM, Lechner JF, LaVeck MA, Sporn MB, et al. (1986) Type beta transforming growth factor is the primary differentiation-inducing serum factor for normal human bronchial epithelial cells. Proc Natl Acad Sci 83: 2438 2442.

20. Siddiqui KM, Chopra DP (1984) Primary and long term epithelial cell cultures from human fetal normal colonic mucosa. In Vitro 20: 859-868.

21. Seidelin JB, Horn T, Nielsen $\mathrm{OH}$ (2003) Simple and efficient method for isolation and cultivation of endoscopically obtained human colonocytes. Am J Physiol Gastrointest Liver Physiol 285: G1122-1128.

22. Potten CS, Loeffler M (1990) Stem cells: attributes, cycles, spirals, pitfalls and uncertainties. Lessons for and from the crypt. Development 110: 1001-1020.

23. Abu-Serie MM, El Demellawy MA, El-Sayed M, El-Rashidy F (2015) In vitro animal cancer model for assessment of sulfated polysaccharides extract of Ulva lactuca as colon cancer therapeutic and chemopreventive agents. Proceedings of the Fourth AACR International Conference on Frontiers in Basic Cancer Research.

24. Föllmann W, Weber S, Birkner S (2000) Primary cell cultures of bovine colon epithelium: isolation and cell culture of colonocytes. Toxicol In Vitro 14: 435-445.

25. Mosmann T (1983) Rapid colorimetric assay for cellular growth and survival application to proliferation and cytotoxicity assays. J Immunol Methods 65: 55-63.

26. Ichinose S, Muneta T, Koga H, Segawa Y, Tagami M, et al. (2010) Morphological differences during in vitro chondrogenesis of bone marrow-, synovium-MSCs, and chondrocytes. Lab Invest 90: 210-221.

27. Tolivia J, Navarro A, Tolivia D (1994) Polychromatic staining of epoxy semithin sections: a new and simple method. Histochemistry 101: 51-55.

28. Bhavanandan VP, Sheykhnazari M, Devaraj H (1990) Colorimetric determination of $\mathrm{N}$-acetylhexosamine-terminating O-glycosidically linked saccharides in mucins and glycoproteins. Anal Biochem 188: 142-148.

29. Bancroft JD, Gamble M (2008) Tissue processing and microtomy: Paraffin and frozen: Theory and Practice of Histological Techniques, Churchill Livingstone Elsevier Press, London.

30. Nkabyo YS, Ziegler TR, Gu LH, Watson WH, Jones DP (2002) Glutathione and thioredoxin redox during differentiation in human colon epithelial (Caco-2) cells. Am J Physiol Gastrointest Liver Physiol 283: G1352-1359.

31. Benton SM, Liang Z, Hao L, Liang Y, Hebbar G, et al. (2012) Differentia regulation of tissue thiol-disulfide redox status in a murine model of peritonitis. J Inflamm (Lond) 9: 36
32. Griffith OW (1980) Determination of glutathione and glutathione disulfide using glutathione reductase and 2-vinylpyridine. Anal Biochem 106: 207-212.

33. Tietze $F$ (1969) Enzymic method for quantitative determination of nanogram amounts of total and oxidized glutathione: Applications to mammalian blood and other tissues. Anal biochem 27: 502-522.

34. Kirlin WG, Cai J, Thompson SA, Diaz D, Kavanagh TJ, et al. (1999) Glutathione redox potential in response to differentiation and enzyme inducers. Free Radic Biol Med 27: 1208-1218.

35. Elmore S (2007) Apoptosis: a review of programmed cell death. Toxicol Pathol 35: $495-516$

36. Oberhammer FA, Hochegger K, Fröschl G, Tiefenbacher R, Pavelka M (1994) Chromatin condensation during apoptosis is accompanied by degradation of lamin $A+B$, without enhanced activation of cdc2 kinase. J Cell Biol 126: 827-837.

37. Helgason CD (2005) Culture of primary adherent cells and a continuously growing nonadherent cell line. Methods Mol Biol 290: 1-12.

38. Kyriakis JM, Avruch J (2001) Mammalian mitogen-activated protein kinase signal transduction pathways activated by stress and inflammation. Physio Rev 81: 807-869.

39. Carpenter G, Cohen S (1979) Epidermal growth factor. Annu Rev Biochem 48: 193-216.

40. Ross R, Raines EW, Bowen-Pope DF (1986) The biology of platelet-derived growth factor. Cell 46: 155-169.

41. Evans GS, Flint N, Somers AS, Eyden B, Potten CS (1992) The development of a method for the preparation of rat intestinal epithelial cell primary cultures J Cell Sci 101: 219-231.

42. Kirchhoff P, Geibel JP (2006) Role of calcium and other trace elements in the gastrointestinal physiology. World J Gastroenterol 12: 3229-3236.

43. Kifor O, MacLeod RJ, Diaz R, Bai M, Yamaguchi T, et al. (2001) Regulation of MAP kinase by calcium-sensing receptor in bovine parathyroid and CaRtransfected HEK293 cells. Am J Physiol Renal Physiol 280: F291-302.

44. Kallay E, Kifor O, Chattopadhyay N, Brown EM, Bischof MG, et al. (1997) Calcium-dependent c-myc proto-oncogene expression and proliferation of Caco-2 cells: A role for a luminal extracellular calcium-sensing receptor. Biochem Biophys Res Commun 232: 80-83.

45. Yoshimura Y, Hisada Y, Suzuki K, Deyama Y, Matsumoto A (1996) Effect of a low-calcium environment on alkaline phosphatase activity in embryonic rat calvarial bone cells in culture. Arch Oral Biol 41: 41-45.

46. Lopez-Cazaux S, Bluteau G, Magne D, Lieubeau B, Guicheux J, et al. (2006) Culture medium modulates the behaviour of human dental pulp-derived cells: technical note. Eur Cell Mater 11: 35-42.

47. Kuilman T, Michaloglou C, Mooi WJ, Peeper DS (2010) The essence of senescence. Genes Dev 24: 2463-2479.

48. Niemelä O (2007) Acetaldehyde adducts in circulation. Novartis Found Symp 285: 183-192.

49. Allahverdiyev AM, Bagirova M, Oztel ON, Yaman S, Abamor ES, et al. (2012) Aldehyde dehydrogenase: Cancer and stem cells: Biochemistry: Genetic and Molecular Biology, Canada.

50. Chavassieux PM, Chenu C, Valentin-Opran A, Merle B, Delmas PD, et al. (1990) Influence of experimental conditions on osteoblast activity in human primary bone cell cultures. J Bone Miner Res 5: 337-343.

51. Coelho MJ, Cabral AT, Fernande MH (2000) Human bone cell cultures in biocompatibility testing. Part I: osteoblastic differentiation of serially passaged human bone marrow cells cultured in alpha-MEM and in DMEM. Biomaterials 21: $1087-1094$

52. Stolzing A, Coleman N, Scutt A (2006) Glucose-induced replicative senescence in mesenchymal stem cells. Rejuvenation Res 9: 31-35.

53. Larsen SA, Kassem M, Rattan SI (2012) Glucose metabolite glyoxal induces senescence in telomerase-immortalized human mesenchymal stem cells Chem Cent J 6: 6-18.

54. Li YM, Schilling T, Benisch P, Zeck S, Meissner-Weigl J, et al. (2007) Effects of high glucose on mesenchymal stem cell proliferation and differentiation. Biochem Biophys Res Commun 363: 209-215. 
Citation: Abu-Serie MM, El Demellawy MA, El-Sayed M, El-Rashidy F (2016) In Vitro Sustained Differentiation of Rat Colon Epithelial Stem Cells. Biochem Anal Biochem 5: 239. doi:10.4172/2161-1009.1000239

Page 8 of 8

55. Kim HS, Park JW, Yeo SI, Choi BJ, Suh JY (2006) Effects of high glucose on cellular activity of periodontal ligament cells in vitro. Diabetes Res Clin Pract 74: 41-47.

56. Aw TY (2003) Cellular redox: a modulator of intestinal epithelial cell proliferation. News Physiol Sci 18: 201-204.

57. Carlisle R, Rhoads CA, Aw TY, Harrison L (2002) Endothelial cells maintain a reduced redox environment even as mitochondrial function declines. Am J Physiol Cell Physiol 283: C1675-1686.

58. Brown KE, Meleah Mathahs M, Broadhurst KA, Coleman MC, Ridnour LA, et al. (2007) Increased hepatic telomerase activity in a rat model of iron overload: a role for altered thiol redox state? Free Radic Biol Med 42: 228-235.

59. Jones DP (2002) Redox potential of GSH/GSSG couple: assay and biological significance. Methods Enzymol 348: 93-112.

60. Conour J, Graham W, Gaskins H (2004) A combined in vitro/bioinformatic investigation of redox regulatory mechanisms governing cell cycle progression Physiol Genomics 18: 196-205.

61. Shaw JP, Chou IN (1986) Elevation of intracellular glutathione content associated with mitogenic stimulation of quiescent fibroblasts. J Cell Physiol 129: 193-198.

62. Circu ML, Aw TY (2012) Intestinal redox biology and oxidative stress. Semin Cell Dev Biol 23: 729-737. 